\title{
NEW HOSTS AND DISTRIBUTION RECORDS OF BRAGA PATAGONICA, A PARASITE CYMOTHOIDAE OF FISHES FROM THE AMAZON
}

\author{
Tavares-Dias, M. ${ }^{1 *}$; Araújo, C. S. O. ${ }^{2,3} ;$ Barros, M. S. ${ }^{3}$ \& Viana, G. M. ${ }^{3}$ \\ 1 - : Embrapa Amapá, Laboratório de Sanidade de Organismos Aquáticos, Macapá, AP, Brasil \\ 2 - Universidade do Estado do Amazonas (UEA), Manaus, AM, Brasil. \\ 3 - Universidade Nilton Lins, Manaus, AM, Brasil. \\ *Corresponding author: marcos.tavares@embrapa.br
}

\begin{abstract}
Tavares-Dias, M; Araújo, C. S. O.; Barros, M. S. \& Viana, G. M. (2014) New hosts and distribution records of Braga patagonica, a parasite cymothoidae of fishes from the Amazon. Braz. J. Aquat. Sci. Technol. 18(1): 91-97. elSSN 1983-9057. DOI: 10.14210/bjast.v18n1.p91-97 Specimens of Braga patagonica Schiödte \& Meinert, 1884 (Isopoda: Cymothoidae) from freshwater fishes deposited in Ichthyological Collection of Amazon National Research Institute (INPA), in central Amazon and from fishes from eastern Amazon (Brazil) were investigated. Prevalence, infection intensity and body measures of $B$. patagonica for different populations of this cymothoid in wild fishes species from Amazon were carried out. Four species of Serrasalmidae, one Characidae, one Cichlidae, one Cynodontidae, one Curimatidae, one Acestrorhynchidae and one Sciaenidae were recorded as new hosts for $B$. patagonica in the Amazon. This study indicates a low intensity and low parasitic specificity of $B$. patagonica, and also recorded the first parasitism by this ectoparasite in farmed Colossoma macropomum, describing its highly pathogenic effect.
\end{abstract}

Keywords: Crustacean, Cymothoid, Freshwater fish, Parasitism

\section{INTRODUCTION}

There are many crustacean parasites of fish in fresh, brackish and salt water, and most of them are found in natural fish populations. Isopod parasites are predominantly associated with marine fish species and only a few of them attack freshwater fish. Isopods of the family Cymothoidae Leach, 1818 covers more than 200 species, all well adapted to parasitism (see Piasecki \& Avenant-Oldewage 2008). Currently, a total of 28 ectoparasite isopods representing 12 genera are known to attack South American freshwater fish and most of them belong to the family Cymothoidae (Carvalho et al., 2004). South America has a greater diversity of Cymothoidae species than any other region of the world (Thatcher, 2006; Eiras et al., 2010). In Brazil, Cymothoidae are the isopods most frequently found in freshwater fish (see Eiras et al., 2010). In terms of taxonomy, Cymothoidae is the least understood family within the suborder Flabellifera and requires a complex revision (Brusca, 1981). Before a revision being possible an extensive research effort is needed on individual species. One of the groups requiring detailed studies are Neotropical cymothoid fish parasites.

Among freshwater cymothoid species the genus Braga was proposed in 1881 to initially accommodate three new species from Brazil: Braga cichlae Shiödte \& Meinert, 1881; Braga nasuta Shiödte \& Meinert, 1881 and Braga brasiliensis Shiödte \& Meinert, 1881. Later, Shiödte \& Meinert, 1881 described a fourth species, the Braga patagonica from the Patagonia coast, near Rio Negro in Argentina. Braga brasiliensis was considered a synonym of $B$. patagonica. Braga fluviatilis Richardson, 1911 and Braga bachmanni Stadler, 1972 (see Lemos de Castro, 1959) were described in Argentina. In the eastern Amazon (State of Amapá), Braga amapaensis Thatcher, 1996 was described from Acestrorhynchus microlepis Jardine, 1841 (= Acestrorhynchus guianensis Menezes, 1969) (Acestrorhynchidae) (see Thatcher, 1996). Recently, Braga cigarra Thatcher, Oliveira \& Garcia, 2009 was described parasitizing Galeocharax knerii Steindachner, 1879 (Characidae) from Rio Grande, in Minas Gerais, Brazil (Thatcher et al., 2009).

The aforementioned cymothoid species were reported as ectoparasites of freshwater fishes from South America (Thun \& Brusca 1980; Brusca, 1981; Thatcher, 2006; Thatcher et al., 2009). However, there have been two erroneous reports on the occurrence of the cymothoids of the genus Braga in the west coast of the United States. Braga occidentalis Boone, 1918 was described, but no host was mentioned and it has been suspected that it was collected from eastern South America and later erroneously reported as being from North America (see Lemos de Castro, 1959; Thun \& Brusca 1980; Brusca, 1981). Ho (1975) also reported Braga sp. from saltwater Hypsopsetta guttulata Girard, 1856 (Pleronectidae), in the coast of the United States (California), but the specimen is probably Elthusa sp. (Thun \& Brusca, 1980).

A relationship between the increase in infestation intensity of $B$. fluviatilis and reduction of the Dolops bidentata Bouvier, 1899 (Branchiura) was observed in Serrasalmus spilopleura Kner, 1858 (Serrasalmidae) in Argentina (Hamann, 1995/1996). In Brazil, studies on the parasitic fauna of wild and farmed Cichla spp. 
have reported the reference of $B$. cichlae in Cichla temensis von Humboldt, 1821 (Cichlidae) (Araújo et al., 2009). Braga patagonica has been reported parasitizing different species of freshwater fish (Lemos de Castro, 1959, Carvalho et al., 2004; Thatcher, 2006) in different environments. According to Lemos de Castro (1959), B. patagonica seems to be the most widespread isopod of this genus. Ectoparasites of the family Cymothoidae tend to be associated with their hosts through their entire life while species of other families are parasites only at their larval phase of life (Piasecki \& Avenant-Oldewage, 2008).

The impact of these isopods on the health of fish is little known, but lesions in the gills are the most common (Eiras et al., 2010), as well as the low parasitic intensity. However, it may cause this impact mortality, or indirectly may act as vectors of diseases, especially those caused by virus (Carvalho et al., 2004, Thatcher 2006) and bacteria. In the gills of the red piranha Pygocentrus nattereri Kner, 1858 (Serrasalmidae) a tumor was found in the operculum, probably caused by $B$. patagonica (see Carvalho et al., 2004). Consequently, these infestations can cause significant economic losses in fish farms (Eiras et al., 2010), which have not been estimated yet. Few data on the infection and transmission rates of $B$. patagonica in Brazilian fish are found and there are no reports on farmed fish.

The aim of this study was to investigate the prevalence and intensity of $B$. patagonica in fish from the Ichthyological Collection of the Laboratory of Fish Parasitology from the Amazon National Research Institute (INPA), in central Amazon, Brazil. In addition, to report the first record of infestation in farmed fish.

\section{MATERIAL AND METHODS}

Fishes were obtained from the Ichthyological Collection of the Laboratory of Fish Parasitology of the Amazon National Research Institute (INPA). The fish collection grew for a period of over twenty years based on donations of a number of researchers. An important contribution was also the fish specimens collected within 1999-2000 with the intention to study parasitic isopods. The collection sites included: Tarumã Mirim Stream, a tributary of the Negro River (0301'44.5'S, 06009'49.1'W) and the Solimões River, near the Marchantaria Island, in the Amazonas River (0314'29.4"S, 05957'03.4'W). The paratypes of species described for the Amazon region and deposited in the Invertebrate Collection of INPA were also analyzed. The gills and mouths of all fish were examined, as well as their external surface, in order to verify the presence of Cymothoidae that pierce the peritoneal cavity. The parasite specimens found were processed for analyses under light microscopy, focusing on the morphological character of pleopods and mouth parts for identification.

In addition, Colossoma macropomum Cuvier, 1818 (980 to $1.816 \mathrm{~g}$ and 39 to $48 \mathrm{~cm}$ ) were collected from a pond of $10,000 \mathrm{~m}^{3}$ containing 5,000 fish in a

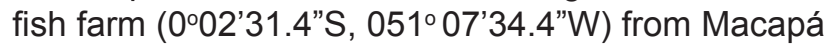
municipality, in the State of Amapá (in eastern Amazon, Brazil) for parasitological analysis. All fish had their external surface, mouth and gills examined for the presence of cymothoids. All the parasites found, in a total of 32 (24 males and 8 females) were collected and deposited in the INPA collection (Voucher: 1874), fixed in $70 \%$ ethanol and identified according to the recommendations of Lemos de Castro (1959) and Thatcher (2006).

\section{RESULTS}

A total of 33 females and 14 males from the Ichthyologic Collection of the Laboratory of Fish Parasitology from Amazon National Research Institute (INPA) deposited in the Invertebrate Collection under the vouchers in Table 1 were examined.

\section{Braga patagonica Schiödte \& Meinert, 1884} (Figure 1)

\section{Diagnostic description}

Females: oval body; light colored (closer to vert 340). Triangular cephalon, long and rounded anterior; long maxillipeds, with side lobes with hairy bristles and relatively small eyes (Table 2 ). Wide pereon, highest and widest at the $5^{\text {th }}$ pereonite. Narrow pleon. Prominent pleotelson, wider than long. Uropod shorther than pleotelson; elongated oval branches; exopodite longer than endopodite.

Males: Smaller than females (Table 2), cephalon and pleon relatively larger than females in proportion to their bodies. Sexual dimorphism evident in the maxilliped, through shape and size and in the second pleopod with a slender male appendix.

\section{Hosts}

Tambaqui Colossoma macropomum Cuvier, 1818; red piranha $P$. nattereri Kner; pacu-manteiga Mylossoma duriventre Cuvier, 1817; redeye piranha Serrasalmus rhombeus Linnaeus, 1766 (Serralmidae); matrinxã Brycon amazonicus Spix and Agassiz, 1829 (Characidae); payara Hydrolycus scomberoides Cuvier, 1819 (Cynodontidae); South American silver croaker Plagioscion squamosissimus Heckel, 1840 
Table 1 - Specimens of $B$. patagonica examined in Ichthyologic Collection of the Laboratory of Fish Parasitology from Amazon National Research Institute (INPA), State of Amazonas, Brazil.

\begin{tabular}{|c|c|c|c|c|}
\hline Site of collection & Host species & Host family & Number of parasites & $\begin{array}{c}\text { INPA } \\
\text { Voucher }\end{array}$ \\
\hline Tarumã-Mirim Stream, Negro River & P. squamosissimus & Sciaenidae & 1 female & 964 \\
\hline Catalão Lake, Solimões River & P. squamosissimus & Sciaenidae & 2 females & 1010 \\
\hline $\begin{array}{l}\text { Jacaretinga Lake near Careiro } \\
\text { Island, Solimões River }\end{array}$ & P. nattereri & Serrasalmidae & 2 males & 965 and 967 \\
\hline $\begin{array}{l}\text { Jacaretinga Lake near Careiro } \\
\text { Island, Solimões River }\end{array}$ & P. nattereri & Serrasalmidae & 2 females & 966 and 969 \\
\hline $\begin{array}{l}\text { Jacaretinga Lake near Careiro } \\
\text { Island, Solimões River }\end{array}$ & P. nattereri & Serrasalmidae & $\begin{array}{l}1 \text { female, part in slide (number } \\
78 \text { ) and part in ethanol }\end{array}$ & 970 \\
\hline $\begin{array}{l}\text { Jacaretinga Lake near Careiro } \\
\text { Island, Solimões River }\end{array}$ & P. nattereri & Serrasalmidae & $\begin{array}{l}1 \text { female, part in slide (number } \\
83 \text { ) and part in ethanol }\end{array}$ & 972 \\
\hline $\begin{array}{l}\text { Jacaretinga Lake near Careiro } \\
\text { Island, Solimões River }\end{array}$ & P. nattereri & Serrasalmidae & 1 female & 971 \\
\hline $\begin{array}{l}\text { Passarinho Lake, near Careiro } \\
\text { Island, Solimões River }\end{array}$ & P. nattereri & Serrasalmidae & 4 females & $\begin{array}{c}973-975 \text { and } \\
984\end{array}$ \\
\hline $\begin{array}{l}\text { Passarinho Lake, near Careiro } \\
\text { Island, Solimões River }\end{array}$ & P. nattereri & Serrasalmidae & $\begin{array}{l}5 \text { males, part in slide (number } \\
90 \text { ) and part in ehtanol }\end{array}$ & $978-982$ \\
\hline $\begin{array}{l}\text { Passarinho Lake, near Careiro } \\
\text { Island, Solimões River }\end{array}$ & P. nattereri & Serrasalmidae & $\begin{array}{l}5 \text { males, part in slide (number } \\
90 \text { ) and part in ehtanol }\end{array}$ & $978-982$ \\
\hline $\begin{array}{l}\text { Passarinho Lake, near Careiro } \\
\text { Island, Solimões River }\end{array}$ & C. macropomum & Serrasalmidae & $\begin{array}{l}1 \text { female, part in slide (number } \\
113 \text { ) and part in ethanol }\end{array}$ & 983 \\
\hline $\begin{array}{l}\text { Inema Lake, near Careiro Island, } \\
\text { Solimões River }\end{array}$ & P. nattereri & Serrasalmidae & $\begin{array}{l}1 \text { female, part in slide (number } \\
29 \text { ) and part in ethanol }\end{array}$ & 986 \\
\hline $\begin{array}{l}\text { Inema Lake, near Janauacá, } \\
\text { Solimões River }\end{array}$ & P. nattereri & Serrasalmidae & $\begin{array}{l}5 \text { females, part in slide (number } \\
106 \text { ) and part in ethanol }\end{array}$ & $\begin{array}{c}987-990 \text { and } \\
992\end{array}$ \\
\hline Solimões River, near Careiro Island & P. nattereri & Serrasalmidae & $\begin{array}{l}1 \text { female, part in slide (number } \\
100 \text { ) and part in ethanol }\end{array}$ & 1005 \\
\hline Solimões River, near Careiro Island & P. nattereri & Serrasalmidae & $\begin{array}{l}1 \text { female, part in slide (number } \\
101 \text { ) and part in ethanol }\end{array}$ & 1006 \\
\hline $\begin{array}{l}\text { Inema Lake, near Janauacá, } \\
\text { Solimões River }\end{array}$ & P. nattereri & Serrasalmidae & $\begin{array}{l}1 \text { male, part in slide (number } \\
110 \text { ) and part in ethanol }\end{array}$ & 991 \\
\hline Janauacá Lake, Solimões River & Serrasalmus sp. & Serrasalmidae & $\begin{array}{l}1 \text { male, } 1 \text { female, part in slide } \\
\text { (number } 27 a, b \text { ) and part in } \\
\text { ethanol }\end{array}$ & 993 \\
\hline Janauacá Lake, Solimões River & Serrasalmus sp. & Serrasalmidae & 1 male & 994 \\
\hline Janauacá Lake, Solimões River & P. nattereri & Serrasalmidae & $\begin{array}{l}1 \text { female, part in slide (number } \\
\text { 102) and part in ethanol }\end{array}$ & 995 \\
\hline Solimões River, near Marchantaria & P. nattereri & Serrasalmidae & $\begin{array}{l}1 \text { female, part in slide (number } \\
103 \text { ) and part in ethanol }\end{array}$ & $\begin{array}{l}996,1000 \\
\text { and } 1001\end{array}$ \\
\hline Catalão Lake, Solimões River & P. nattereri & Serrasalmidae & 2 females & $1011-1012$ \\
\hline Catalão Lake, Solimões River & P. nattereri & Serrasalmidae & 1 male & 1013 \\
\hline $\begin{array}{l}\text { Gamboa Lake near Careiro Island, } \\
\text { Solimões River }\end{array}$ & P. nattereri & Serrasalmidae & 1 female & 1014 \\
\hline $\begin{array}{l}\text { Solimões River, near Marchantaria } \\
\text { Island }\end{array}$ & S. rhombeus & Serrasalmidae & 1 male & 997 \\
\hline $\begin{array}{l}\text { Solimões River, near Marchantaria } \\
\text { Island }\end{array}$ & M. duriventre & Serrasalmidae & 1 female & 998 \\
\hline $\begin{array}{l}\text { Solimões River, near ilha da } \\
\text { Marchantaria }\end{array}$ & B. amazonicus & Characidae & 1 male & 1002 \\
\hline $\begin{array}{l}\text { Solimões River, near Marchantaria } \\
\text { Island }\end{array}$ & B. amazonicus & Characidae & 1 female & 1004 \\
\hline Catalão Lake, Solimões River & B. amazonicus & Characidae & $\begin{array}{l}1 \text { female, part in slide (number } \\
112 \text { ) and part in ethanol }\end{array}$ & 1009 \\
\hline $\begin{array}{l}\text { Solimões River, near Marchantaria } \\
\text { Island }\end{array}$ & C. orbicularis & Cichlidae & 1 male & 1003 \\
\hline Solimões River & H. scomberoides & Cynodontidae & 1 female & 1007 \\
\hline $\begin{array}{l}\text { Inema Lake, near Janauacá, } \\
\text { Solimões River }\end{array}$ & P. nattereri & - & 1 male & 1008 \\
\hline
\end{tabular}



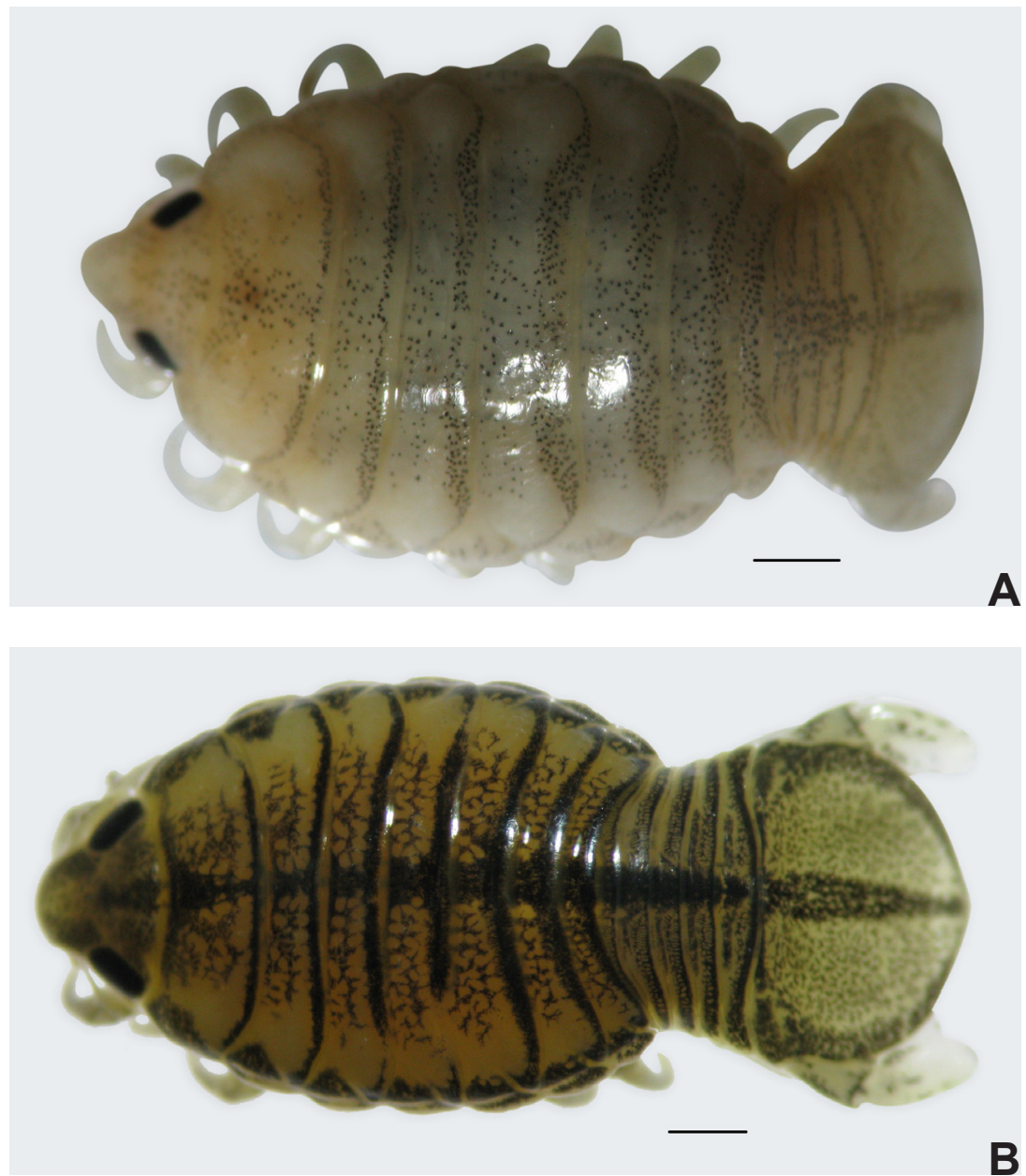

Figure 1 - Braga patagonica (A) female, (B) male, collected in Amazonian fish from the Ichthyologic Collection from INPA, central Amazon, Brazil. Bar: $1 \mathrm{~mm}$.

(Sciaenidae) and acará Chaetobranchopsis orbicularis Steindachner, 1875 (Cichlidae).

Site of attachment of the parasite

Mouth or ventral part of the gill chamber.

\section{Localities of parasites collection}

State of Amazonas, central Amazon, Brazil.

Tarumã-Mirim Stream, Rio Negro; Jacaretinga Lake near Careiro Island, Solimões River; Passarinho Lake, near Careiro Island, Solimões River; Inema Lake, near Janauacá, Solimões River; Janauacá Lake, Solimões River near Marchantaria Island; Solimões River near Careiro Island; Catalão Lake; Gamboa Lake near Careiro Island in Solimões River (central Amazon).

State of Pará, eastern Amazon, Brazil. Cruz Alta Lake, Trombetas River (eastern Amazon).

\section{Prevalence}

Ichthyologic Collection: 4/10 299×100\% $=0.04 \%$; Solimões River near Marchantaria Island: $22 / 514 \times 100 \%=4.28 \%$; Tarumã-Mirim Stream, State of Amazonas: $2 / 158 \times 100 \%=1.26 \%$.

\section{Intensity of infection}

1-2 parasites/host.

\section{Specificity}

Species of Amazonian cymothoid that presents the smallest parasitic specificity and found more frequently in Serrasalmidae species.

\section{Type of hosts}

Species of Loricaridae not identified; Pogonias cromis Linnaeus, 1766 (Sciaenidae); Salminus hilarii Géry, 1977 (Characidae) (Lemos de Castro, 1959; Thatcher, 1991, 2006); Hoplias malabaricus Bloch, 1794 (Erythrinidae) (Thatcher, 1991, 2006) and P. nattereri (Carvalho et al., 2004).

\section{Type of locality}

Coast of Patagonia, near Negro River in the Argentina, Assunção and Paraguai; São Francisco River in the States of Minas Gerais and Bahia; Belém in the State of Pará (Lemos de Castro, 1959) and Araguaia River in the State of Goiás, Brazil (Carvalho et al., 2004). 


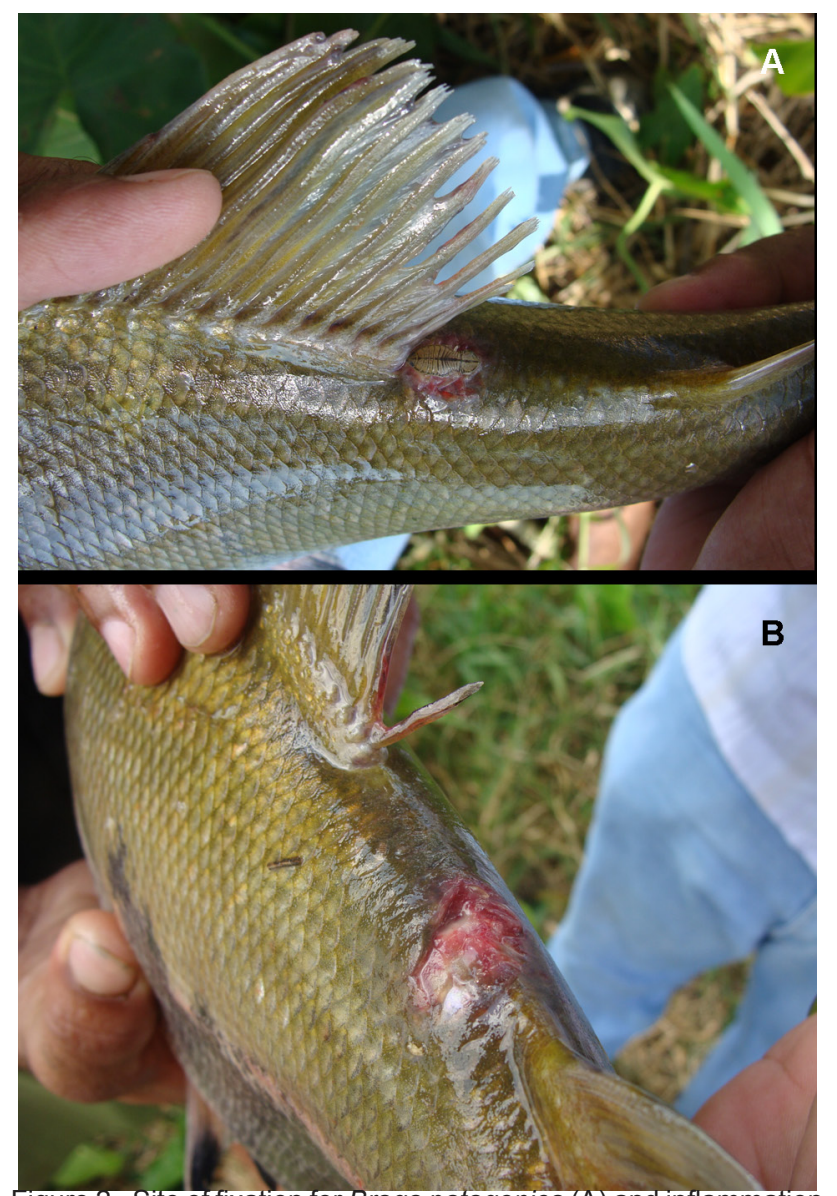

Figure 2 - Site of fixation for Braga patagonica (A) and inflammation at the site of attachment in farmed Colossoma macropomum (B) from the eastern Amazon, Brazil.

\section{State of Amapá, eastern Amazon, Brazil. Infection in farmed fish species.}

Out of 500 C. macropomum examined in one fish farm from the eastern Amazon, 30.0\% had the body dorsal area parasitized by a specimen of this cymothoid (Figure 2A), which was always found near the fin. Body measurements of these crustacean parasites are shown in Table 3.

The attachment of the ectoparasites in this skin area of $C$. macropomum has probably facilitated its attachment and feeding and caused the destruction of the scales and inflammation at the site of attachment to the host (Figure 2B). Therefore, following the parasitological analysis and the collection of parasites, the tank was submitted to a treatment with $100 \mathrm{~g} / 1000 \mathrm{~m}^{3}$ of Diflubenzuron, which eliminated the parasitism. After five days this tank was submitted to three consecutive treatments of salt $\left(500 \mathrm{~g} / \mathrm{m}^{3}\right)$ for recovering the damages in the fish skin.

The source of parasitism indicated that the crustaceans $B$. patagonica were brought to the culture pond of $C$. macropomum by invader fish such as $H$. malabaricus, Curimata cyprinoides Linnaeus, 1766 (Curimatidae) and Acestrorhynchus falcatus Bloch,
Table 2 - Measurements $(\mathrm{mm})$ of males, females and transition of Braga patagonica of Amazonian fish from the Ichthyologic Collection from INPA, central Amazon, Brazil. L: length; W: width; N: number of examined specimens; SD: standard deviation

\begin{tabular}{|c|c|c|c|c|c|c|}
\hline & & & $\mathbf{N}$ & Range & Mean & SD \\
\hline Female & Body & $\begin{array}{l}\mathrm{L} \\
\mathrm{W}\end{array}$ & $\begin{array}{l}33 \\
33\end{array}$ & $\begin{array}{r}13.91-24.31 \\
6.50-13.52\end{array}$ & $\begin{array}{r}18.20 \\
8.90\end{array}$ & $\begin{array}{l}2.55 \\
1.68\end{array}$ \\
\hline Male & Body & $\begin{array}{l}C \\
W\end{array}$ & $\begin{array}{l}14 \\
14\end{array}$ & $\begin{array}{l}6.90-21.45 \\
3.04-11.31\end{array}$ & $\begin{array}{r}13.50 \\
6.30 \\
\end{array}$ & $\begin{array}{l}4.13 \\
2.52 \\
\end{array}$ \\
\hline
\end{tabular}

Table 3 - Measurements $(\mathrm{mm})$ of males, females and transition of Braga patagonica in farmed Colossoma macropomum from eastern Amazon, State of Amapá, Brazil. L: length; W: width; N: number of examined specimens; SD: standard deviation.

\begin{tabular}{lcccrrr}
\hline \hline & & & $\mathbf{N}$ & \multicolumn{1}{c}{ Range } & Mean & SD \\
\hline Female & Body & L & 8 & $12.53-18.27$ & 15.89 & 1.74 \\
& & W & 8 & $6.82-8.76$ & 7.91 & 0.63 \\
Male & Body & L & 24 & $5.65-11.44$ & 8.93 & 1.38 \\
& & W & 24 & $2.36-5.37$ & 4.00 & 0.68 \\
\hline \hline
\end{tabular}

1794 (Acestrorhynchidae). These fish invaded the culture ponds through the water supply of fish farm and $B$. patagonica was also found in the gills of these invading fish collected in the water supply channel of Fortaleza Stream, in areas near the fish farm, and a mean of 2 parasites per host were collected.

\section{DISCUSSION}

Male cymothoid are free-living animals and female cymothoids are obligate parasites. They begin their lives as males and then turn into females (Araújo \& Thatcher, 2006; Thatcher, 2006). For this reason, studies on $B$. patagonica have usually used only females for biometric measurements and taxonomic identification. Females of $B$. patagonica from the States of Amazonas and Pará had $18.2 \mathrm{~mm}$ mean length and the males, $13.5 \mathrm{~mm}$, while females from the State of Amapá showed $15.89 \mathrm{~mm}$ mean length and males, $8.93 \mathrm{~mm}$. Therefore, these results confirm that females are larger than males. Lemos de Castro (1959) cited that Schiödte \& Meinert (1884) have recorded $20.0 \mathrm{~mm}$ in length for the type specimen from the coast of Patagonia in Argentina, while Cordeiro (1937) reported $28.0 \mathrm{~mm}$ in length and $16.0-16.5 \mathrm{~mm}$ in width for two females collected in fish from the State of Pernambuco, Brazil.

A survey of crustaceans from the Sucuriju and Lakes regions in the State of Amapá, in the North Brazil, has reported the occurrence of $B$. patagonica in the marginal and aquatic vegetation of the floodplain forest (Vieira, 2006). This increases the parasitism possibility in fish that moves in areas of aquatic vegetation.

The pathogenicity of the ectoparasite isopods varies according to their location in the host, feeding behavior, strategy of attack and the parasite size 
(Thatcher, 2006; Piasecki \& Avenant-Oldewage, 2008; Eiras et al., 2010). Studies suggest that both, feeding sites and body size, probably play important role in the distribution and abundance of fish ectoparasites (Carvalho et al., 2004). For the most part, ectoparasite isopods of freshwater fish have well defined sites of attachment. Thatcher (2006) described that cymothoid species of the genus Braga infest the ventral part of the opercular cavity or the mouth of their hosts. In contrast, Carvalho et al. (2004) reported that the gills of $P$. nattereri were the attachment sites of $B$. patagonica. However, all farmed C. macropomum here examined had the dorsal region of the body as the only attachment site of $B$. patagonica.

In a fish farm from eastern Amazon, in the State of Amapá, $30.0 \%$ of the C. macropomum specimens were parasitized by $B$. patagonica, which caused the destruction of scales and a severe inflammation in the skin of this host. However, this infection in fish skin has been not yet documented, because the parasitism of gills is the most common (Eiras et al., 2010). In P. nattereri, from Araguaia River, the prevalence of B. patagonica was $88.8 \%$ and a tumor was found in the operculum, probably caused by the ectoparasite (Carvalho et al., 2004). This ectoparasite causes considerable injury to their hosts, once it seems to feed from mucous and epithelial cells, perforating the fish skin. Thus, they represent a major problem for Amazonian fish farms because they compromise the appearance of the fish intended to be commercialized. Nevertheless, the lesions of gills and a low parasitic intensity are the most common in wild fish populations. Since this infection on C. macropomum skin has been uncommon, further studies in other farmed fish species are need to understand the parasite-host-environment relationship.

In fish farm, to control infections by $B$. patagonica was used $100 \mathrm{~g} / 1000 \mathrm{~m}^{3}$ of diflubenzuron in pond, which has eliminated this ectoparasite. In Brazil, this product has also been used to control other crustacean ectoparasites, because it has low toxicity to fish (Kreutz et al., 2008, Tavares-Dias et al., 2011). In order to be suitable for fish farming, a chemical product must be safe for fish, highly efficient and rapidly degraded, not interfering with the water, easily applicable and low cost.

In conclusion, this study indicates a low parasitic specificity of $B$. patagonica, besides enlarged the occurrence of this for new hosts in Brazilian Amazon such as the $C$. macropomum, S. rhombeus, M. duriventre, $S$. spilopleura, B. amazonicus, C. orbicularis, H. scomberoides and $P$. squamosissimus, from Trombetas River (State of Pará), Rio Negro, Solimões River and from several lakes and streams of the State of Amazonas, as well as $C$. cyprinoide and $A$. falcatus from State of
Amapá. This is the first report of $B$. patagonica infecting and causing injury in farmed fish.

\section{ACKNOWLEDGEMENTS}

The authors thank Conselho Nacional de Pesquisa e Desenvolvimento Tecnológico (CNPq) for supporting this Research (\# 578159/2008-2). M. Tavares-Dias was supported by a Research fellowship from Conselho Nacional de Pesquisa e Desenvolvimento Tecnológico (CNPq).

\section{REFERENCES}

Araújo, C.S.O. \& Thatcher, V.E. 2006. Biologia reprodutiva de cymothoidae (Isopoda) da Amazônia brasileira. CIVA2006, p.1153-1163. Disponível em: http://www.revistaaquatic.com/civa2006.

Araújo, C.S.O.; Barros, M.C.; Gomes A.L.S; Varella,A.M.B.; Viana G.M.V.N.P.; Fraga, E.C. \& Andrade, S.M.S. 2009. Parasitas de populações naturais e artificiais de tucunaré (Cichla spp.). Rev. Bras. Parasitol. Vet. 18: 34-38.

Brusca, R.C. 1981. A monograph on the Isopoda Cymothoidae (Crustacea) of the eastern Pacific. Zoological J. Linnean Soc. 73: 117-199.

Carvalho, L.N.; Arruda, R. \& Del-Claro, K. 2004. Host-parasite interactions between the piranha Pygocentrus nattereri (Characiformes: Characidae) and isopods and branchiurans (Crustacea) in the Araguaia River basin, Brazil. Neotrop. Ichthyol. 2: 93-98.

Cordeiro, E.H. 1937. Nerocila fluviatilis y otros isopodos parasites de las famílias Cymothoidae y Bopyridae del Uruguay y del Brasil. An. Mus. Hist. Nat. Montevideo 4: 1-11.

Eiras, J.C.; Takemoto, R.M. \& Pavanelli, G.C. 2010. Diversidade dos parasitos de peixes de água doce do Brasil. Clichetec, Maringá, 333p.

Hamann, M.I. 1995/1996. Fauna parasitaria de Serrasalmus spilopleura Kner, 1860 em ambinetes leniticos de la província de Corrientes, Argentina. Rev. Ictiol. 4: 11-17.

Ho, J.S. 1975. Parasitic crustacea. Proc. Philad. Acad. Nat. Sci. 7:175-177.

Kreutz, L.C.; Barcellos, L.J.G.; Silva, T.O.; Anziliero, D.; Martins, D.; Lorenson, M.; Marteninghe, A. \& Silva, L.B. 2008. Acute toxicity test of agricultural pesticides on silver catfish (Rhamdia quelen) fingerlings. Ciência Rural 38: 1050-1055.

Lemos de Castro, A. 1959. Sobre as espécies sulamericanas do gênero Braga Schioedte et Meinert, 
1881 (Isopoda: Cymothoidae). Arq. Museu Nac. Rio de Janeiro 59: 69-77.

Piasecki, W. \& Avenant-Oldewage, A. 2008. In: Eiras, J.C.; Segner, H.; Wahli, T. \&. Kapoor, B.G (ed), Fish diseases. Science Publisher, New Hampshire. 1115-1200pp.

Tavares-Dias, M.; Neves, L.R.; Santos, E.F.; Dias, M.K.R.; Marinho, R.G.B. \& Ono, E.A. 2011. Perulernaea gamitanae (Copepoda: Lernaeidae) parasitizing tambaqui (Colossoma macropomum) (Characidae) and the hybrids tambacu and tambatinga, cultured in Northern Brazil. Arq. Bras. Med. Vet. Zootec. 63: 988-995.

Thatcher, V.E. 1996. Braga amapaensis n.sp. (Isopoda: Cymothoidae) a mouth cavity parasite of the Amazonian fish, Acestrorhynchus guyanensis Menezes. Amazoniana 14: 311-322.

Thatcher, V.E. 2006. Amazon fish parasites. Pensoft, Sofia, 508p.

Thatcher, V.E.; Oliveira, A.A.N. \& Garcia, A.M. 2009. Braga cigarra comb. nov for Philostomella cigarra with a redescription of the species based on specimens from Galeocharax kneri, a freshwater fish Minas Gerais State, Brasil. Zoologia 26: 155-160.

Thun, M. \& Brusca, R.C. 1980. On the status of the eastern Pacific cymothoid fish parasite Braga occidentalis Boone, and its synonymy with $B$. patagonica Schioedte and Meinert (Crustacea: Isopoda: Cymothoidae). Bull. South. Calif. Acad. Sci. 79: 130-132.

Vieira, I.M. 2006. Inventário biológico da carcinofauna das áreas Sucuriju e região dos Lagos, Amapá. In: S.V. Costa Neto (Org.). Inventário biológico das áreas do Sucuruju e região dos Lagos no Amapá: Relatório Final Probio. IEPA, Macapá.143-155pp.

Submetido: Novembro/2012 Revisado: Dezembro/2013 Aceito: Fevereiro/2014 